\title{
Reduced Tillage Impacts on Pumpkin Yield, Weed Pressure, Soil Moisture, and Soil Erosion
}

\author{
Megan E. O'Rourke ${ }^{1}$ \\ Department of Horticulture, Virginia Tech, 490 West Campus Drive, \\ Blacksburg, VA 24061
}

\section{Jessica Petersen \\ Minnesota Department of Natural Resources, 35365 800th Avenue, Madelia, MN 56062}

Additional index words. no-till, strip-till, conventional-till, Cucurbita pepo, flooding, climate change adaptation

\begin{abstract}
Conservation tillage has the potential to decrease the environmental footprint of pumpkin production, but possible trade-offs with yield are not well understood. This study experimentally tested the effects of three cultivation techniques (conventional-till, strip-till, and no-till) on pumpkin production, weed pressure, soil moisture, and soil erosion. Randomized complete block field experiments were conducted on Cucurbita pepo L. 'Gladiator' pumpkins in 2014 and 2015. Overall yields were higher in 2015, averaging $45.2 \mathrm{t} \cdot \mathrm{ha}^{-1}$, compared with $37.4 \mathrm{t} \cdot \mathrm{ha}^{-1}$ in 2014. In 2014, pumpkin yields were similar across tillage treatments. In 2015, the average fruit weight of no-till pumpkins was significantly greater than strip-till and conventional-till pumpkins, which corresponded to a marginally significant $13 \%$ and $22 \%$ yield increase, respectively $(P=0.11)$. Weed control was variable between years, especially in the strip-till treatment. Soil moisture was consistently highest in the no-till treatment in both years of study. Conventional-till pumpkin plots lost $\approx 9$ times more soil than the two conservation tilled treatments during simulated storm events. The 2015 yield advantage of no-till pumpkins seems related to both high soil moisture retention and weed control. Research results suggest that no-till and strip-till pumpkin production systems yield at least as well as conventional-till systems with the advantage of reducing soil erosion during extreme rains.
\end{abstract}

Over 35,000 ha of pumpkins (Cucurbito pepo L.) are grown each year in the United States resulting in farm receipts of about $\$ 170$ million (Lucier and Dettmann, 2007; USDA-NASS, 2012). Jack-o-lantern pumpkins represent a major portion of the industry and are typically grown regionally due to the high cost of shipping (Lucier and Dettmann, 2007). As such, they are grown under a wide variety of production scenarios with states as different as California, Texas, and New York among the top 10 producers of fresh market pumpkins (USDA-NASS, 2012).

Given the diversity of locations where pumpkins are produced in the United States, it is useful to develop production technologies that can be integrated into different systems and that appeal to general consumer demand. Increasingly, consumers are demanding

Received for publication 3 Aug. 2016. Accepted for publication 6 Oct. 2016.

This work was supported by start-up funds provided to M.E. O'Rourke through the college of agriculture and life sciences at Virginia Tech.

We thanks to V. Groover and S. Francis for support with field work and to T. Kuhar, A. Straw, and R. Morse for thoughtful feedback about the project and manuscript.

${ }^{1}$ Corresponding author. E-mail: megorust@vt.edu. products with reduced environmental impact. Consumers prefer to purchase produce that has low environmental impact if it does not increase price (Dimitri and Greene, 2002). Meanwhile, climate scientists predict increased average temperatures and frequency of extreme weather events like drought and flood, which can significantly disrupt production systems if growers do not adapt (IPCC, 2013, Walsh et al., 2014). Already across the United States, average temperatures have increased significantly during the 20th century, and the number of extreme precipitation events during the period 1957-2010 has also increased, especially in the Midwest, southeast, and northeast (Kunkel et al., 2013; Walthall et al., 2012). Adopting conservation tillage systems may be a means of meeting consumer demand for more sustainable products while adapting to climate change (Lal, 2007).

No-till is one form of conservation tillage that has been widely adopted in agronomic cropping systems to reduce soil erosion and improve sustainability (Derpsch et al., 2010). In contrast, no-till vegetable production is relatively rare due to challenges with delayed soil warming, reduced germination and root growth, and weed control (Hoyt et al., 1994). However, pumpkin production may be particularly amenable to a no-till system (Harrelson et al., 2008). Pumpkins are planted well after frost when soils have had time to warm, seeds are large and germinate reliably, and plants can create a canopy that shades out weeds (Bratsch, 2009; Hoyt et al., 1994).

Strip-till pumpkin production is an alternative conservation tillage strategy that may combine the benefits of conventional-till and no-till systems. Strip tillage is a form of reduced tillage where the planting zone is tilled and the rest of the soil remains undisturbed. This provides a friable seedbed similar to conventional-till systems while leaving the rest of the soil undisturbed. However, there are some indications that weeds are more problematic in strip-till compared with no-till and conventional-till systems (Hoyt et al., 1994; Morse, 1999). It is also unclear whether erosion control and soil moisture retention will be as great in strip-till as no-till systems (Fernández et al., 2015). Furthermore, there has been little research on strip tillage as part of a pumpkin production system or comparing strip-till to no-till pumpkin production.

Cover cropping can be an essential part of a conservation tillage system by providing a mulch layer to retain soil moisture, reduce erosion, suppress weeds, and keep fruits dry. Cover crop residue can reduce water evaporation and water runoff, which reduces irrigation needs and soil erosion (Lal, 2004). Cover crop mulch can suppress weeds by physical interference and/or allelopathy throughout the production season (Barnes and Putnam, 1983; Creamer et al., 1996), which can potentially reduce the need for herbicides (Hartwig and Ammon, 2002). A thick cover crop residue layer can also keep fruits off the soil surface and relatively dry, which can help manage disease pressure and reduce the need for fungicides (Everts, 2002; Ogutu, 2004).

This research compares the effects of notill, strip-till, and conventional-tillage in a rain-fed pumpkin production system that included cover cropping during the winter. Previous studies do not show clear impacts of tillage on pumpkin production. Rapp et al. (2004) reported that pumpkin yields in no-till were greater than in both strip-till and disked plots. Similarly, Walters et al. (2008) found that no-till pumpkin yields were nearly double conventional-till yields. On the other hand, Ogutu (2004) found that conventional-till resulted in greater pumpkin yields than striptill systems.

We hypothesized that pumpkin yields in reduced tillage systems, including no-till and strip-till, would be equivalent to conventionaltill. Furthermore, we hypothesized that reduced tillage would have the added benefit of protecting soils under extreme rainfall events. We also tracked weeds and soil moisture in the different tillage systems to understand the mechanisms by which tillage could impact yields. We hypothesized that weed control would be higher in no-till than in strip-till and conventional-till pumpkin production, and that soil moisture would be highest in no-till, lowest in conventional-till, and intermediate in strip-till. 


\section{Materials and Methods}

Site description and experimental design. Field experiments were conducted in 2014 and 2015 at Virginia Tech's Kentland Farm in Blacksburg, VA. The soil at the experimental site is a Hayter loam in hydrologic soil group A and the land has $2 \%$ to $7 \%$ slope (NRCS, 2016). Before the experiment, the site had been in alfalfa production since 2008 . The experiment was laid out as a randomized complete block design with four replicates. The main treatment in both years was tillage: conventional-till, strip-till, and no-till. In 2014, there was an additional split-plot treatment: simulated flooding and ambient rainfall. Each experimental unit measured $7 \times 14.5 \mathrm{~m}$ in both years so that the total experimental area was twice as large in 2014 (with tillage and flooding treatments) compared with 2015 (only tillage treatments). Plots in 2015 were in the same physical location as one half of the plots in 2014 but with a new randomization of treatments. Pumpkin rows were spaced $1.8 \mathrm{~m}$ apart and each plot consisted of four rows with 13 plants spaced equidistantly $(1.2 \mathrm{~m})$ within each row. The field was planted with 18 jack-o-lantern type 'Gladiator' pumpkins (Harris Seeds, Rochester, NY) planted in the center of the plot ( 9 plants/row $\times$ 2 rows). 'Field Trip' pumpkins (Stokes Seeds, Buffalo, NY), which have smaller fruits than 'Gladiator', were planted in the two outside rows of all plots and at the first and last two plant sites at the ends of plots. The 'Field Trip' pumpkins served to eliminate edge effects in the test pumpkins and visually differentiated 'Gladiator' and 'Field Trip' fruits. In 2014, the plots that received simulated flooding treatments were only used to assess soil erosion and were not used for any other measurements.

Pumpkin production. Across the entire experimental area, a cover crop was seeded on 16 Oct. 2013 (50\% rye and 50\% winter pea) and 27 Oct. 2014 (50\% rye, 25\% vetch, and 25\% winter pea) at a rate of $112 \mathrm{~kg} \cdot \mathrm{ha}^{-1}$. Vetch was added to the cover crop mix in 2014 with the goal of increasing the proportion of legume biomass. Cover crops were treated with glyphosate (4.7 L.ha ${ }^{-1}$ ) on 14 May 2014 and 20 May 2015. One day before glyphosate applications, cover crop biomass was sampled using one $0.5 \times$ $0.5 \mathrm{~m}$ quadrat per plot in 2014 and two of the same-sized quadrats per plot in 2015; samples were dried at $65{ }^{\circ} \mathrm{C}$ before weighing. The desiccated cover crop in no-till plots was rolled on 2 June 2014 and 1 June 2015 using a flail mower (Alamo-Mott Brand, Seguin, TX) with the blades turned off. The conventional-till and striptill plots were mowed using a Woods BW 183Series 3 mower. Conventional-till plots were chisel plowed on 4 June 2014 and 31 May 2015. They received an additional tillage treatment in 2014 only using a KUHN EL62 rotary tiller (Brodhead, WI) on 10 June. In 2014, strip-tilling was conducted using a multivator (Ford Distributing, Inc., Marysville, $\mathrm{OH}$ ) to mimic the strip tiller's disc on 16 June. In 2015, strip tilling was conducted using a Troybilt model walk behind rototiller on 10 June. The width of the strips was $\approx 40 \mathrm{~cm}$ in both years of study.
All plots were broadcast fertilized before planting on 2 June $2014(10 \mathrm{~N}-10 \mathrm{P}-10 \mathrm{~K}$ at $\left.448 \mathrm{~kg} \cdot \mathrm{ha}^{-1}\right)$ and 11 May $2015(10 \mathrm{~N}-20 \mathrm{P}-$ $20 \mathrm{~K}$ at $\left.560 \mathrm{~kg} \cdot \mathrm{ha}^{-1}\right)$. Given the field's history in alfalfa, we chose fertilizer rates on the conservative end of the fertilizer recommendations for Virginia, with an increase in the second year to try to achieve higher yields (VCE, 2014). Plots were hand seeded on 18 June 2014 and 11 June 2015 with two 'Gladiator' seeds per germination site, which were then thinned to one plant after germination. 'Gladiator' seed was treated with mefenoxam (Apron XL), fludioxonil (Maxim), and azoxystrobin (Dynasty) fungicides, and thiamethoxam (Cruiser 5FS) insecticide. A pre-emergent herbicide mix composed of ethalfluralin (Curbit at 2.34 $\mathrm{L} \cdot \mathrm{ha}^{-1}$ ) + paraquat (Gramoxone at 2.92 $\mathrm{L} \cdot \mathrm{ha}^{-1}$ ) + nonionic surfactant (Induce at $0.25 \% \mathrm{v} / \mathrm{v}$ ) was applied to all plots on 19 June 2014 and 12 June 2015, both one day after planting (DAP). Postemergent herbicides were applied only in 2015 on 7 July (26 DAP): halosulfuron-methyl (Sandea at $0.05 \mathrm{~L} \cdot \mathrm{ha}^{-1}$ ) + sethoxydim (Poast at $2.3 \mathrm{~L} \cdot \mathrm{ha}^{-1}$ ) + nonionic surfactant (Induce at $0.25 \% \mathrm{v} / \mathrm{v}$ ).

Fungicides and insecticides were used on developing plants (VCE, 2014). There was only one insecticide application during the study on 23 July 2014 (35 DAP), using esfenvalerate (Asana XL at $0.7 \mathrm{~L} \cdot \mathrm{ha}^{-1}$ ). In 2014, fungicide applications consisted of chlorothalonil (Bravo Weatherstik at 3.5 L $\cdot \mathrm{ha}^{-1}$ ) on
23 July (35 DAP), chlorothalonil (3.5 L $\left.\cdot \mathrm{ha}^{-1}\right)+$ cyazofamid (Ranman at $0.2 \mathrm{~L} \cdot \mathrm{ha}^{-1}$ ) on $15 \mathrm{Aug}$. (58 DAP), and chlorothalonil (3.5 L.ha $\left.{ }^{-1}\right)+$ cymoxanil (Curzate at $0.4 \mathrm{~L} \cdot \mathrm{ha}^{-1}$ ) on $22 \mathrm{Aug}$. (65 DAP). In 2015, fungicide applications consisted of chlorothalonil $\left(3.5 \mathrm{~L} \cdot \mathrm{ha}^{-1}\right)+$ Fontelis $\left(0.4 \mathrm{~L} \cdot \mathrm{ha}^{-1}\right)$ on 27 July (46 DAP), chlorothalonil $\left(3.5 \mathrm{~L} \cdot \mathrm{ha}^{-1}\right)+$ azoxystrobin (Abound at $0.4 \mathrm{~L} \cdot \mathrm{ha}^{-1}$ ) on 5 Aug. (55 DAP), and chlorothalonil $\left(3.5 \mathrm{~L} \cdot \mathrm{ha}^{-1}\right)+$ cyazofamid (0.2 L.ha ${ }^{-1}$ ) on 19 Aug. (69 DAP).

All fruits from the 18 'Gladiator' plants in each plot were counted and harvested on 8 Oct. 2014 (112 DAP) and 7 Oct. 2015 (118 DAP). Fruits were categorized by color (orange or green) and quality (damaged or undamaged) at the time of harvest. Damage included rot or extensive scarring of the skin. Only orange, undamaged fruits were considered marketable and used to determine yield; data on green fruit are not reported. In 2014, all the marketable fruits were weighed in the entire plot to determine yields. In 2015, marketable fruit yields were estimated by multiplying the number of fruits in different size categories by the average weights of those sized pumpkins. Fruit size was categorized as small ( $<70 \mathrm{~cm}$ circumference), medium (70-85 $\mathrm{cm}$ circumference), or large $(>80 \mathrm{~cm}$ circumference). The average weight of each size class was determined by weighing up to three fruits per size class from each plot and averaging across all the plots ( $\approx 36$ pumpkins per size class). Estimated
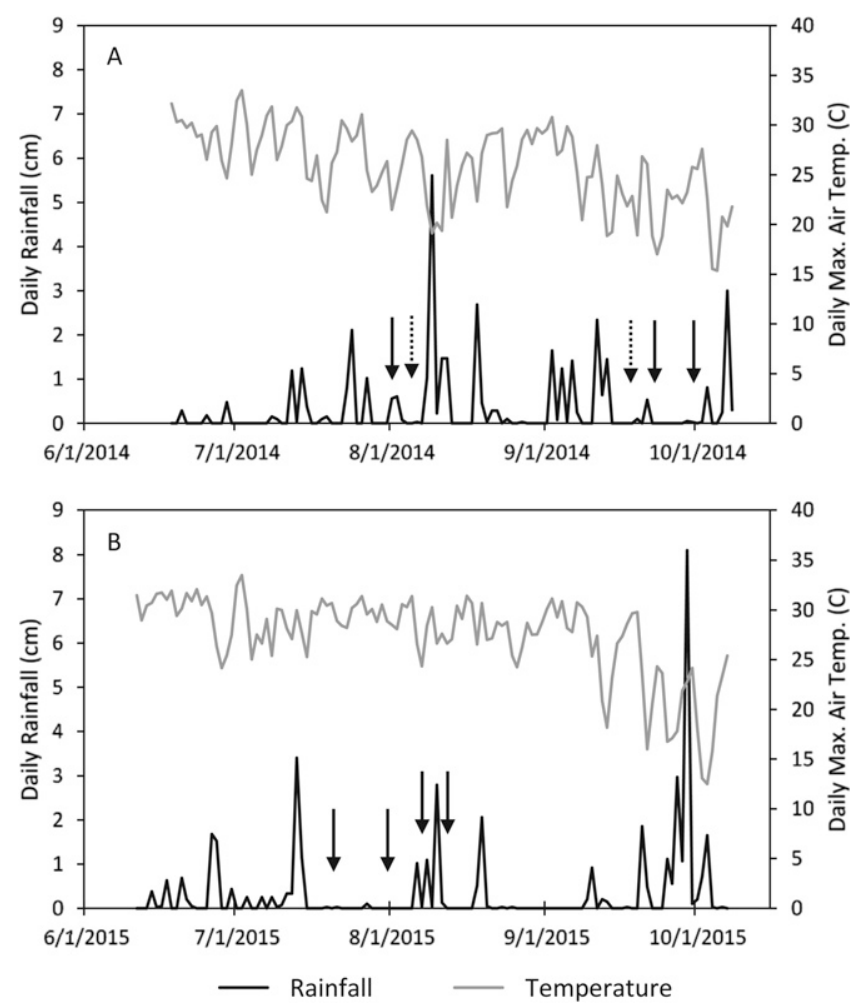

Fig. 1. Daily rainfall (black line) and maximum air temperature (gray line) during the 2 years of study in (A) 2014 and (B) 2015. Solid arrows point to soil moisture sampling dates (2 Aug., 2014, 45 DAP; 23 Sept., 2014, 97 DAP; and 1 Oct., 2014, 105 DAP; 20 July, 2015, 39 DAP; 29 July, 2015, 48 DAP; 6 Aug., 2015, 56 DAP, and 11 Aug., 2015, 61 DAP). Dotted arrows point to rainfall simulation dates (5 Aug., 2014, 48 DAP and 17 Sept., 2014, 91 DAP). 
Table 1. Mean and standard error statistics associated with pumpkin production under three different tillage regimes: no-till (NT), strip-till (ST), and conventional-till (CT), across two study years.

\begin{tabular}{lccccc}
\hline Study yr & $\begin{array}{c}\text { Tillage } \\
\text { treatment }\end{array}$ & Avg wt pumpkin $(\mathrm{kg})^{\mathrm{z}}$ & Yield $\left(\mathrm{kg} \cdot \mathrm{ha}^{-1}\right)^{\mathrm{z}}$ & $\begin{array}{c}\text { No. of marketable } \\
\text { pumpkins/ha }\end{array}$ & $\begin{array}{c}\text { No. of damaged } \\
\text { pumpkins/ha }\end{array}$ \\
\hline 2014 & NT & $7.82 \pm 0.04$ & $39,698 \pm 1,067$ & $5,077 \pm 118$ & $125 \pm 0$ \\
& ST & $7.46 \pm 0.22$ & $36,025 \pm 1,922$ & $4,828 \pm 179$ & $125 \pm 0$ \\
& CT & $7.80 \pm 0.29$ & $36,590 \pm 2,489$ & $4,703 \pm 319$ & $187 \pm 80$ \\
2015 & NT & $6.73 \pm 0.17 \mathrm{a}^{\mathrm{y}}$ & $50,151 \pm 5,044$ & $7,413 \pm 614$ & $62 \pm 62$ \\
& ST & $5.99 \pm 0.08 \mathrm{~b}$ & $44,432 \pm 3,298$ & $7,413 \pm 542$ & $249 \pm 102$ \\
& CT & $5.84 \pm 0.11 \mathrm{~b}$ & $41,006 \pm 1,932$ & $7,039 \pm 436$ & $311 \pm 120$ \\
\hline
\end{tabular}

${ }^{\mathrm{z}}$ Pumpkin weight and yield are based on only those fruit that were marketable (orange and undamaged) at the time of harvest.

${ }^{\mathrm{y}}$ The only significant differences between tillage treatment effects were for average weights per pumpkin in 2015 at $\alpha \leq 0.05$ level using Tukey honestly significant difference tests.

Table 2. Mean and standard error statistics of weed and soil impacts in pumpkins produced under three different tillage regimes: no-till (NT), strip-till (ST), and conventional-till (CT), across two study years.

\begin{tabular}{lcccc}
\hline Study yr & $\begin{array}{c}\text { Tillage } \\
\text { treatment }\end{array}$ & Dried weed wt $\left(\mathrm{g} \cdot \mathrm{m}^{-1}\right)$ & Soil moisture $(\%)^{\mathrm{z}}$ & $\begin{array}{c}\text { Total suspended solids } \\
\left(\mathrm{mg} \cdot \mathrm{L}^{-1}\right)^{\mathrm{y}}\end{array}$ \\
\hline 2014 & $\mathrm{NT}$ & $71.0 \pm 11.7 \mathrm{~b}^{\mathrm{x}}$ & $28.79 \pm 0.42 \mathrm{ab}$ & $218.57 \pm 66.82 \mathrm{a}$ \\
& ST & $200.0 \pm 32.7 \mathrm{c}$ & $29.20 \pm 0.76 \mathrm{a}$ & $169.73 \pm 26.22 \mathrm{a}$ \\
& $\mathrm{CT}$ & $28.9 \pm 9.0 \mathrm{a}$ & $25.65 \pm 1.01 \mathrm{~b}$ & $1,715.51 \pm 292.43 \mathrm{~b}$ \\
2015 & NT & $5.6 \pm 4.5 \mathrm{NS}$ & $23.56 \pm 1.01 \mathrm{a}$ & - \\
& ST & $13.5 \pm 4.9 \mathrm{NS}$ & $19.59 \pm 1.15 \mathrm{ab}$ & - \\
& CT & $28.5 \pm 18.1 \mathrm{NS}$ & $16.76 \pm 2.09 \mathrm{~b}$ & - \\
\hline
\end{tabular}

${ }^{\mathrm{z}}$ Soil moisture data are the averages of three sampling dates in 2014 (2 Aug., 45 DAP; 23 Sept., 97 DAP; and 1 Oct., 105 DAP), and four in 2015 (20 July, 39 DAP; 29 July, 48 DAP; 6 Aug., 56 DAP; and 11 Aug., 61 DAP).

${ }^{\mathrm{y}}$ Total suspended solids data are the averages from runoff samples following two rainfall simulations in 2014 (5 Aug., 48 DAP and 17 Sept., 91 DAP); rainfall simulations were not conducted in 2015.

${ }^{\mathrm{x}}$ Letters denote significant differences among tillage treatments for each response variable within years at $\alpha \leq 0.05$ level using Tukey honestly significant difference tests.

NS $=$ no significant differences among treatments.

yields using this method differed from weighing all the pumpkins in two plots by $\approx 1 \%$.

Soil erosion, soil moisture, and weeds. A flooding simulation experiment was conducted in 2014 to mimic the extreme flooding events predicted under climate change. Flooding simulations were conducted using an oscillating nozzle rainfall simulator (Tlaloc 3000 Rainfall Simulator, Joern's Inc., West Lafayette, IN) placed $1.8 \mathrm{~m}$ above the erosion plot and turned on for $30 \mathrm{~min}$. The amount of water added to the erosion plots was $4.4 \pm 0.09 \mathrm{~cm}$. This amount represents a heavy storm and is near to the $5.0 \mathrm{~cm}$ daily rainfall estimated to have historically occurred about once per year in Virginia (Kunkel et al., 1999). Runoff was collected from erosion plots by sinking strips of metal sheets $10 \mathrm{~cm}$ into the ground to form a border around the 'Gladiator' pumpkins $(2.1 \times 2 \mathrm{~m})$ with a funnel-shaped collection pan at one end. Runoff was analyzed in the laboratory for total suspended solids (TSS) using a standard filtration process (APHA, 1995). Two rainfall simulation experiments were conducted in 2014 on 5 Aug. (48 DAP) and 17 Sept. (91 DAP) with such strong and consistent effects on TSS that the rainfall simulations were not continued in 2015.

Soil moisture was measured using a Model 6050X1 Trase System Time-Domain Reflectometer (Santa Barbara, CA). Measurements were taken at $22 \mathrm{~cm}$ depth using $0.25-\mathrm{cm}$ diameter stainless steel brazing rods that were pounded into the soil between plants within the 'Gladiator' rows of the experimental plots. Soil moisture content was averaged across two subsamples in each plot. Samples were taken three times in 2014 (2 Aug., 45 DAP; 23 Sept., 97 DAP; and 1 Oct., 105 DAP), and four times in 2015 (20 July, 39 DAP; 29 July, 48 DAP; 6 Aug., 56 DAP; and 11 Aug., 61 DAP). Measurements were taken during a variety of growing conditions including hotter and cooler periods in 2014, and wetter and drier periods during rapid vine growth in 2015 (Fig. 1).

Weeds were sampled from plots on 5 Sept. 2014 (79 DAP) and 24 Aug. 2015 (74 DAP). In 2014, weeds were sampled using a $0.5 \times 0.5 \mathrm{~m}$ quadrat that was randomly placed between 'Gladiator' rows at two locations in each plot. In 2015, all the weeds surrounding the 'Gladiator' pumpkins up to the border rows of 'Field Trip' pumpkins were harvested. Weeds were cut at ground level and dried at $65^{\circ} \mathrm{C}$. Dried weed weights were standardized to $\mathrm{g} \cdot \mathrm{m}^{-2}$.

Statistical analysis. Data were analyzed separately each year using JMP software. Data were examined using standard least squares models that included tillage as a main treatment effect and block as a random factor. In 2014, simulated flooding plots were analyzed for TSS while all other response variables were analyzed from ambient rainfall plots. Where there were statistically significant treatment effects, all pairwise contrasts were analyzed using Tukey honestly significant difference at $\alpha=0.05$ level. Dried weed weight was $\log$ transformed to meet assumptions of normality.

\section{Results and Discussion}

Growing conditions and management were somewhat different in the 2 years of study and may have contributed to higher overall yields in 2015 that averaged 52.5 t.ha ${ }^{-1}$ compared with $37.4 \mathrm{t} \cdot \mathrm{ha}^{-1}$ in 2014 (Table 1). Cover crop residue at termination averaged $8.0 \pm 0.7$ tons $\cdot \mathrm{ha}^{-1}$ in 2014, and $9.1 \pm 0.9$ tons $\cdot \mathrm{ha}^{-1}$ in 2015 . Total rainfall and average high temperature were $37.5 \mathrm{~cm}$ and $26.0{ }^{\circ} \mathrm{C}$, respectively, during the pumpkin growing season in 2014, while there was $40.0 \mathrm{~cm}$ of rain and an average high of $27.4^{\circ} \mathrm{C}$ in 2015 . Temporal differences in rainfall between the 2 years included more early summer and fall rain in 2015 than in 2014 (Fig. 1). In addition, there was $25 \%$ more $\mathrm{N}$ and over twice the amount of phosphorous and potassium applied in 2015 compared with 2014. Nevertheless, yields in both years were well within the range of normal for the growing region (Bratsch, 2009; Harrelson et al., 2008).

No-till and strip-till 'Gladiator' pumpkin production systems yielded at least as well as conventional-till over the 2 years of this study. Average pumpkin fruit weight was not significantly different among tillage treatments in $2014(F=1.36, P=0.32$; Table 1$)$. However, in 2015 , average pumpkin fruit weight differed among treatments with significantly larger pumpkins in the no-till treatment compared with the strip-till and conventional-till treatments $(F=21.18, P=$ 0.002 ) (Table 1). With a similar number of pumpkins produced in all three tillage treatments in 2015, this translated into a $22 \%$ higher average yield in no-till than conventional-till pumpkins, though this result was not statistically significant at $\alpha=$ 0.05 level $(F=3.13, P=0.11)$. Low numbers of fruit in 2014 translated to fruit weight per pumpkin being higher in 2014 than 2015 (Reiners and Riggs, 1997), but this was not sufficient to produce total yields per hectare that were as high in 2014 as in 2015 (Table 1). These results are consistent with other published studies demonstrating that conservation tillage can produce high pumpkin yields (Hoyt, 1999; Rapp et al., 2004; Walters et al., 2008). Fruit damage was low among all treatments in both years of study (Table 1).

Weed management is an important facet of a pumpkin production system that can be affected by tillage and can ultimately affect yield (Walters et al., 2008; Walters and Young, 2010). Tillage treatment was a significant factor predicting average dried weed weight in $2014(F=29.70, P=0.0008)$ and there were significantly more weeds in the strip-till treatment compared with no-till and conventional-till treatments (Table 2). The five most common weeds in the study were hairy galinsoga (Galinsoga ciliata), redroot pigweed (Amaranthus retroflexus), common lambsquarters (Chenopodium album), yellow nutsedge (Cyperus esculentus), and common purslane (Portulaca oleracea). Along the edges of the tilled strips, weeds were vigorous, and perhaps competed with pumpkin plants, potentially reducing yields in strip-till plots in 2014. In 2015, weeds were better controlled compared with 2014 , possibly due to the postemergence herbicide application 
that year. Better weed control in 2015 may have also contributed to overall higher yields that year compared with 2014 (Table 1). Variable weed control between years in notill and strip-till treatments indicates that careful weed management may be key to successful conservation-tillage pumpkin production (Chauhan et al., 2012).

Soil moisture retention can be another important benefit of a reduced tillage system (Blevins et al., 1983). There was a significant tillage treatment effect on soil moisture content in both years of study (2014: $F=$ $6.49, P=0.03 ; 2015: F=7.79, P=0.02)$. Soil moisture content averaged over three sample dates in 2014 and four sample dates in 2015 was higher in the strip-till and no-till treatments compared with the conventional-till treatment in both years (Table 2). In 2014, soil moisture measurements taken on $23 \mathrm{Sept}$. (97 DAP) and 1 Oct. (105 DAP), when the weather had started to cool, did not differ significantly among tillage treatments, whereas the measurement on 2 Aug. (45 DAP), during a period of rapid vine growth, showed significant tillage treatment effects ( $F=20.85, P=<0.0001)$ with strip-till and no-till treatments similarly retaining about $25 \%$ more moisture than the conventional-till treatment. In 2015, soil moisture measurements were all taken during the hot months of July and August during the period of rapid vine growth and showed consistent trends on all dates and significant treatment effects for all but the last sampling date (11 Aug., 61 DAP). Soil moisture in no-till was significantly higher on 20 July (39 DAP), 29 July (48 DAP), and 6 Aug. (56 DAP) than in conventional-till plots, with intermediate soil moisture in strip-till plots. These results indicate that one potential mechanism of greater pumpkin yield and fruit weight in reduced tillage treatments may be due to greater soil moisture retention.

Consistent with other research on the benefits of strip-till and no-till production systems, soil erosion was greatly reduced in these treatments compared with the conventional-till treatment (Blevins et al., 1983). TSS from runoff following simulated flooding was significantly different between tillage treatments $(F=28.85, P=0.0002)$. On both rainfall simulation dates, there were similar levels of runoff in strip-till and notill treatments, which were significantly less than in the conventional-till treatment (Table 2). In fact, there was 10.8 and 6.9 times as much soil in the runoff from conventional-till plots compared with the average across notill and strip-till treatments on the first (6 Aug., 2014, 48 DAP) and second (17 Sept., 2014, 91 DAP) rainfall simulation dates, respectively. These differences were readily apparent with runoff from the conservation tillage treatments being considerably clearer than the obviously muddy runoff from conventional-till plots with TSS levels in the conservation tillage samples almost as low as the $100 \mathrm{mg} / \mathrm{L}$ level allowed in rivers near the experiment site (VDEQ, 2003). Since these simulated rainfall events represent storm levels that have historically only occurred about once per year (Kunkel et al., 1999), and TSS measured in waterways are the result of all different surrounding land-uses, many of which cause less erosion than agriculture (VDEQ, 2003), conservation tillage in pumpkin production would likely help maintain TSS in waterways below total maximum daily load targets. In addition to conserving water quality, preventing soil erosion through conservation tillage can be important for maintaining the longterm fertility of production fields, especially on sloped land (Pimentel et al., 1995).

Strip-till and no-till pumpkin production were compatible with the relatively lowinput system studied here, which also incorporated cover crops, low fertilizer rates, scouting to reduce pesticide sprays, and no irrigation (Harrelson et al., 2007, 2008; Heckman et al., 2003; Rapp et al., 2004; Reiners and Riggs, 1997; Walters et al., 2008). Strip-till and no-till may be particularly useful in maintaining high pumpkin yields during dry years due to enhanced soil moisture retention in these systems. They also provide the added benefit of conserving soil during extreme rainfall events. Developing low input, conservation tillage vegetable production systems may become increasingly important as a means of adapting to the erratic rainfall patterns predicted by climate change while reducing fuel consumed for tillage (Clements et al., 1995) and meeting customer demands for high-quality products.

\section{Literature Cited}

American Public Health Association (APHA). 1995. Solids, p. 214-227. In: A.D. Eaton, L.S Clesceri, and A.E. Greenberg (eds.). Standard methods for the examination of water and wastewater. Washington, DC.

Barnes, J.P. and A.R. Putnam. 1983. Rye residues contribute weed suppression in no-tillage cropping systems. J. Chem. Ecol. 9:1045-1057.

Blevins, R.L., M.S. Smith, G.W. Thomas, and W.W. Frye. 1983. Influence of conservative tillage on soil properties. J. Soil Water Conserv. 38:301-304.

Bratsch, A. 2009. Specialty crop profile: Pumpkins. Virginia Coop. Ext. Publ. 438-100. Virginia Polytech. Inst. and State Univ., Blacksburg, VA.

Chauhan, B.S., R.G. Singh, and G. Mahajan. 2012. Ecology and management of weeds under conservation agriculture: A review. Crop Prot. 38:57-65.

Clements, D.R., S.F. Weise, R. Brown, D.P. Stonehouse, D.J. Hume, and C.J. Swanton. 1995. Energy analysis of tillage and herbicide inputs in alternative weed management systems. Agr. Ecosyst. Environ. 52:119-128.

Creamer, N.G., M.A. Bennett, B.R. Stinner, J. Cardina, and E.E. Regnier. 1996. Mechanisms of weed suppression in cover crop-based production systems. HortScience 31:410-413.

Derpsch, R., T. Friedrich, A. Kassam, and L. Hongwen. 2010. Current status of adoption of no-till farming in the world and some of its main benefits. Intl. J. Agr. Biol. Eng. 3: $1-25$.

Dimitri, C. and C. Greene. 2002. Recent growth patterns in the U.S. organic food market. Agri. Info. Bul. No. 777. U.S. Dept. Agr. Econ. Res. Serv. Washington, DC.
Everts, K.L. 2002. Reduced fungicide applications and host resistance for managing three diseases in pumpkin grown on a no-till cover crop. Plant Dis. 86:1134-1141.

Fernández, F.G., B.A. Sorensen, and M.B. Villamil. 2015. A comparison of soil properties after five years of no-till and strip-till. Agron. J. 107:1339-1346.

Harrelson, E.R., G.D. Hoyt, J.L. Havlin, and D.W. Monks. 2008. Effect of planting date and nitrogen fertilization rates on no-till pumpkins. HortScience 43:857-861.

Hartwig, N.L. and H.U. Ammon. 2002. Cover crops and living mulches. Weed Sci. 50:688-699.

Heckman, J.R., S. Johnston, and W. Cowgill. 2003. Pumpkin yield and disease response to amending soil with silicon. HortScience 38:552-554.

Hoyt, G.D. 1999. Tillage and cover residue effects on vegetable yields. HortTechnology 9:351-358.

Hoyt, G.D., D.W. Monks, and T.J. Monaco. 1994. Conservation tillage for vegetable production. HortTechnology 4:129-135.

IPCC. 2013. Climate change 2013: The physical science basis. Contribution of working Group I to the fifth assessment report of the intergovernmental panel on climate change. In: Stocker, T.F., D. Qin, G.-K. Plattner, M. Tignor, S.K. Allen, J. Boschung, A. Nauels, Y. Xia, V. Bex, and P.M Midgley (eds.). Cambridge University Press, Cambridge, United Kingdom and New York, NY.

Kunkel, K.D., K. Andsager, and D.R. Easterling. 1999. Long-term trends in extreme precipitation events over the conterminous United States and Canada. J. Clim. 12:2515-2527.

Kunkel, K.E., K.R. Thomas, H. Brooks, J. Kossin, J.H. Lawrimore, D. Arndt, L. Bosart, D. Changnon, S.L. Cutter, N. Doesken, K. Emanuel, P.Y. Groisman, R.W. Katz, T. Knutson, J. O'Brien, C.J. Paciorek, T.C. Peterson, K. Redmond, D. Robinson, J. Trapp, R. Vose, S. Weaver, M. Wehner, K. Wolter, and D. Wuebbles. 2013. Monitoring and understanding trends in extreme storms, state of knowledge. Bull. Amer. Meteorol. Soc. 94:499-514.

Lal, R. 2004. Soil carbon sequestration impacts on climate change and food security. Science 304:1623-1627.

Lal, R. 2007. Carbon management in agricultural soils. Mitig. Adapt. Strategies Glob. Change 12:303-322.

Lucier, G. and R. Dettmann. 2007. Vegetables and melons outlook. VGS-323. U.S. Dept. Agr. Econ. Res. Serv. Washington, DC.

Morse, R.D. 1999. No-till vegetable production: Its time is now. HortTechnology 9:373-379.

Natural Resources Conservation Service (NRCS). 2016. Web soil survey. U.S. Dept. Agr. 13 May 2016. <http://websoilsurvey.nrcs.usda.gov/>.

Ogutu, M. 2004. Strip tillage pumpkin production using rye, and rye/hairy vetch cover crop. HortScience 39:749.

Pimentel, D., C. Harvey, P. Resosudarmo, K. Sinclair, D. Kurz, M. Mcnair, S. Crist, L. Shpritz, L. Fitton, R. Saffouri, and R. Blair. 1995. Environmental and economic costs of soil erosion and conservation benefits. Science 267:1117-1123

Rapp, H.S., R.R. Bellinder, H.C. Wien, and F.M. Vermeylen. 2004. Reduced tillage, rye residues, and herbicides influence weed suppression and yield of pumpkins. Weed Technol. 18:953-961.

Reiners, S. and D.I.M. Riggs. 1997. Plant spacing and variety affect pumpkin yield and fruit size, but supplemental nitrogen does not. HortScience 32:1037-1039.

USDA-NASS. 2012. Census of agriculture. U.S. Dept. Agr. Natl. Agr. Stat. Serv., Washington, DC. 
Virginia Department of Environmental Quality (VDEQ). 2003. Benthic TMDL for stroubles creek in Montgomery County, Virginia. 29 July 2016. <http://www.deq.virginia.gov/portals/0/ DEQ/Water/TMDL/apptmdls/newrvr/stroub.pdf $>$.

Virginia Cooperative Extension (VCE). 2014. Commercial Vegetable Production Recommendations. Pub. No. 456-420. Blacksburg, VA.

Walters, S.A., B.G. Young, and R.F. Krausz. 2008. Influence of tillage, cover crop, and preemergence herbicides on weed control and pumpkin yield. Intl. J. Veg. Sci. 14:148-161.

Walters, S.A. and B.G. Young. 2010. Effect of herbicide and cover crop on weed control in notill jack-o-lantern pumpkins (Cucurbita pepo L.) production. Crop Prot. 29:30-33.
Walsh, J., D. Wuebbles, K. Hayhoe, J. Kossin, K. Kunkel, G. Stephens, P. Thorne, R. Vose, M. Wehner, J. Willis, D. Anderson, S. Doney, R. Feely, P. Hennon, V. Kharin, T. Knutson, F. Landerer, T. Lenton, J. Kennedy, and R. Somerville. 2014. Our changing climate, p. 19-67. In: J.M. Melillo, T.C. Richmond, and G.W. Yohe (eds.). Climate change impacts in the United States: The third national climate assessment, U.S. Global Change Research Program, Washington, DC.

Walthall, C.L., J. Hatfield, P. Backlund, L. Lengnick, E. Marshall, M. Walsh, S. Adkins, M. Aillery, E.A. Ainsworth, C. Ammann, C.J. Anderson, I. Bartomeus, L.H. Baumgard, F. Booker,
B. Bradley, D.M. Blumenthal, J. Bunce, K. Burkey, S.M. Dabney, J.A. Delgado, J. Dukes, A. Funk, K. Garrett, M. Glenn, D. A. Grantz, D. Goodrich, S. Hu, R.C. Izaurralde, R.A.C. Jones, S.-H. Kim, A.D.B. Leaky, K Lewers, T.L. Mader, A. McClung, J. Morgan, D.J. Muth, M. Nearing, D.M. Oosterhuis, D. Ort, C. Parmesan, W.T. Pettigrew, W. Polley, R. Rader, C. Rice, M. Rivington, E. Rosskopf, W.A. Salas, L.E. Sollenberger, R. Srygley, C. Stöckle, E.S. Takle, D. Timlin, J.W. White, R. Winfree, L. Wright-Morton, and L.H. Ziska. 2012. Climate change and agriculture in the United States: Effects and adaptation. USDA Tech. Bul. 1935. Washington, DC. 